\title{
Pelatihan Akuntansi Pemerintahan dan Pengelolaan Dana Desa Pada MGMP Kabupaten Madiun
}

\author{
Elly Astuti ${ }^{* 1}$, Juli Murwani ${ }^{2}$, Sugiharto ${ }^{3}$ \\ 1,2Universitas PGRI Madiun, ${ }^{3}$ Politeknik Negeri Madiun \\ 1,2Program Pendidikan Akuntansi, FKIP, Universitas PGRI Madiun \\ *e-mail: ellyastuti@unipma.ac.id ${ }^{1}{ }_{\text {jmurwani@unipma.ac.id }}^{2}{ }^{2} \underline{\text { sugiharto@pnm.ac.id }}^{3}$
}

\begin{abstract}
Changes to regulations on village government accounting and the need for transparency in financial management are increase; however this is not supported by the availability of adequate human resources. Responding to that, there was a change in the curriculum at the level of vocational high schools which required public sector accounting to become the main competency. The policy has an impact on the availability of teacher human resources who are not familiar with the material. For this purpose, public sector accounting and village fund management services were carried out in coordination with the implementation team, MGMP and IAI Madiun commissariat. As a result of these community service activities, additional knowledge and knowledge of teachers regarding government accounting and village fund management was obtained. The teacher can understand and analyze a transaction to be journalized on a karual or cash basis and can determine the realm and authority of the party carrying out accounting records.
\end{abstract}

Keywords: government accounting, village fund management, accrual basis and cash basis

\begin{abstract}
Abstrak
Perubahan regulasi pada akuntansi pemerintahan desa serta kebutuhan untuk transparansi pengelolaan keuangan semakin tinggi, namun demikian hal ini kurang didukung dengan ketersediaan SDM yang memadai. Menanggapi hal itu, terjadilah perubahan kurikulum pada tataran sekolah menengah kejuruan yang mewajibkan akuntansi sektro publik menjadi kompetensi utama. Kebijakan tersebut berdampak pada ketersedian SDM guru yang kurang menguasa materi. Untuk itu dilakukan pengabdian akuntansi sektor publik dan pengelolaan dana desa dengan koordinasi tim pelaksana, MGMP dan IAI kommisariat Madiun. Hasil dari kegiatan pengabdian ini, diperoleh tambahan ilmu dan pengetahuan guru mengenai akuntansi pemerintahan dan pengelolaan dana desa. Guru dapat memahami dan menganalisis suatu transaksi untuk dijurnal menggunakan basis karual ataupun basis kas serta dapat mementukan ranah dan wewenang pihak yang melakukan pencatatan akuntansi.
\end{abstract}

Kata kunci: akuntansi pemerintahan, pengelolaan dana desa, basis akrual dan basis kas

\section{PENDAHULUAN}

Penerbitan Undang-undang Desa Nomor 6 Tahun 2014 memberikan otoritas yang besar kepada kepala desa untuk menyelenggarakan pemerintahan desa, melaksanakan pembangunan desa, pembinaan kemasyarakatan desa, dan pemberdayaan masyarakat desa (Hadi, 2015). Otoritas tersebut tentu didukung oleh alokasi dana APBN yang cukup besar ke desa. Desa menerima kurang lebih satu milyar per tahun. Hal ini tentu diimbangi dengan kewajiban pelaporan untuk menjamin akuntabilitas dan transparansi penggunaan anggaran. Namun demikian, banyak kepala desa yang menghadapi kendala pelaporan karena kurangnya SDM yang memadai (Manafe, 2019). Beberapa masalah pelaporan terjadi karena data akuntansi yang tidak valid ataupun masalah penguasaan sistem aplikasi akuntansi desa. 


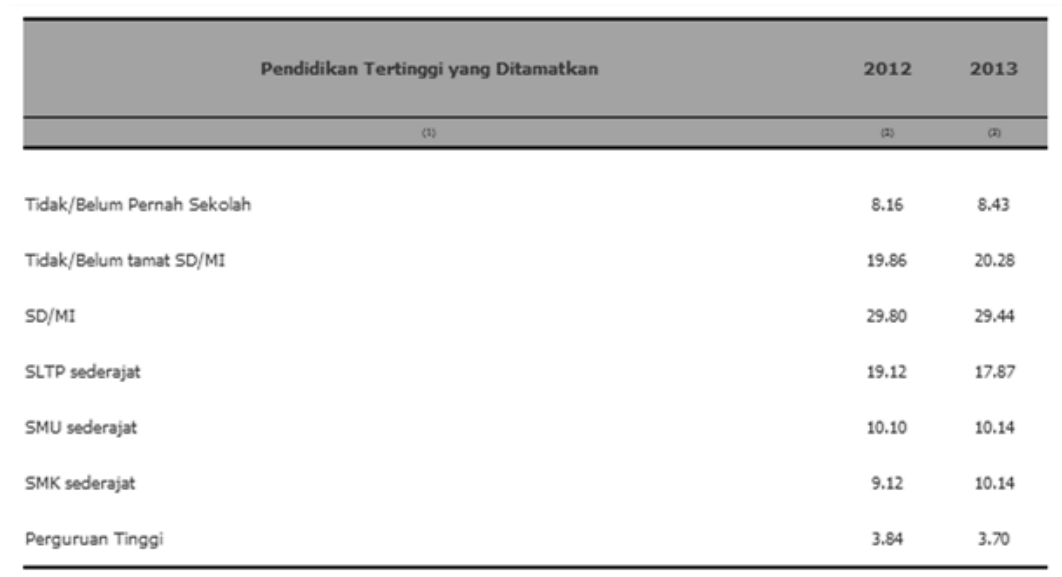

Gambar 1. Presentase Pendidikan Kabupaten Madiun Tahun 2012-2013

(Badan Pusat Statistik, 2015)

Berdasarkan Gambar 1 dapat diketahui bahwa mayoritas penduduk kabupaten madiun menamatkan jenjang pendidikan dasar sampai menengah. Hanya sedikit yang melanjutkan sampai jenjan D3 ataupun S1. Hal membuktikan bahwa ketersediaan SDM yang memahami akuntansi dalam pelaporan keuangan desa sangat terbatas. Rata-rata penduduk dan perangkat desa yang ada berpendidikan setara sekolah menengah atas. Untuk itu perlu penyesuaian kurikulum sekolah menengah yang merupakan presentasi SDM yang umumnya berada pada jajaran pemerintahan desa.

Pada tahun 2018, diterbitkan Peraturan Dirjen Pendidikan Dasar dan Menengah Kementrian Pendidikan dan Kebudayaan Nomor 07/D/D5/KK/2018 tentang Struktur Kurikulum Sekolah Menengah Kejuruan. Pada struktur kurikulum SMK yang baru, Praktikum Akuntansi Lembaga / Instansi Pemerintah merupakan salah satu mata pelajaran baru yang diwajibkan menjadi kompetensi utama SMK jurusan akuntansi dan keuangan. Hal ini merupakan bentuk sinergi sekolah dengan dunia usaha dan industri untuk melaksanakan program link and match, dimana kebutuhan dunia usaha dan industri menjadi prioritas arah pengembangan kurikulum karena pada akhirnya mereka lah yang akan menyerap lulusan SMK(Bakrun, 2019). Kebijakan tersebut diharapkan dapat mengatasi masalah SDM dalam pelaporan keuangan desa yang ada, karena mayoritas jajaran pengurus desa berpendidikan setara sekolah menengah atas.

Perubahan kebijakan kurikulum tentu berdampak pada kebijakan kegiatan belajar dan mengajar di Sekolah. Beberapa sekolah menghadapi kendala dalam SDM yang berkompeten dalam bidang akuntansi pemerintahan, sehingga kebijakan perubahan kurikulum tersebut belum tercapai secara optimal. Mata pelajaran praktikum akuntansi lembaga / instansi pemerintahan yang seharusnya dilaksanakan selama 280 jam pembelajaran hanya membahas teori dan kasus yang ada dalam buku dengan sumber pengetahuan yang terbatas. Hal ini berdampak pada kesiapan lulusan untuk mengabdi dan berpartisipasi pada lingkungan pemerintahan desa yang kurang optimal.

Berdasarkan pada latar belakang permasalahan tersebut, kami memandang perlu untuk melaksanakan pengabdian masyarakat mengenai akuntansi pemerintahaan dan pengelolaan dana desa. Untuk mendukung kegiatan ini, kami berkerja sama dengan MGMP dan Ikatan Akuntansi Indonesia (IAI) Komisariat Madiun. Setelah melaksanakan kegiatan ini, kami berharap terjadi peningkatan kualitas pembelajaran di Sekolah utamanya pada mata pelajaran akuntansi praktikum akuntansi lembaga / instansi pemerintah yang pada akhirnya mampu menyediakan SDM sesuai dengan kebutuhan masyarakat dan dunia industri. 


\section{METODE}

Kegiatan ini dilakukan dalam bentuk pelatihan akuntansi pemerintahaan dan pengelolaan dana desa yang dilakukan selama 3 hari yang meliputi konsep teori, praktik dan penugasan mandiri. Pemberian konsep teori dilakukan dengan menggunakan metode ceramah yaitu pemateri memberikan pengarahan dan peserta mendengarkan(Wardi, Liviawati, \& Putri, 2017). Konseptualisasi teori meliputi regulasi yang mendasari penyusunan laporan keuangan sektor publik serta bagaimana siklus akuntansinya. Untuk memudahkan peserta memahami konsep teori, materi disesuaikan dengan akuntansi rumah tangga sederhana namun tidak terlepas dari konsep dasar akuntansi pemerintahan dan tetap sesuai jalur regulasi yang berlaku.

Praktik akuntansi pemerintahan dan pengelolaan dana desa dilakukan secara manual dan terintegrasi dengan aplikasi. Pada proses manual, peserta diberikan latihan soal terkait penerimaan pendapatan serta alokasi beban dan belanja yang umumnya terjadi pada instansi pemerintah. Pada sesi aplikasi, peserta diberikan sofware aplikasi siskeudes untuk melakukan pencatatan transaksi akuntansi simulasi pada sistem aplikasi. Pada kesempatan ini, peserta juga diberikan pemahaman mengenai audit pengelolaan dan desa agar dapat membangun pemahaman mereka secara holistik.

Pada penugasan mandiri, peserta kembali diberikan soal-soal latihan sesuai dengan pembahasan pada hari 1 -2 mengenai pembuatan laporan keuangan yang sesuai dengan regulasi dan standar akuntansi pemerintah yang berlaku. Tugas mandiri ini nantinya akan direview oleh tim pengabdian masyarakat untuk membuat rencana tindak lanjut atas pelaksanaan program pelatihan yang telah dilaksanakan.

\section{HASIL DAN PEMBAHASAN}

Peserta pelatihan akuntansi pemerintah dan pengelolaan dana desa ini berjumlah 42 guru yang berasal dari berbagai sekolah yang ada pada wilayah kabupaten Madiun, Ngawi, Ponorogo dan Kediri. Kegiatan pengabdian dilaksanakan selama tiga hari yaitu 24 - 26 Januari 2020 di Aula SMKN 1 Geger. Kegiatan ini juga dihadiri oleh Ketua Dinas Pendidikan Kabupaten Madiun, Wakil Kepala Akademik SMKN 1 Geger dan Wakil Ketua IAI Komisariat Madiun.

Pelatihan pada hari pertama dimulai dengan konsep umum akuntansi pemerintahan yang digunakan dalam penyusunan laporan keuangan lembaga / instansi pemerintah. Pada sesi ini dijelaskan mengenai konsep pengakuan, pengukuran, penyajian dan pengungkapan pendapatan, beban dan belanja. Peserta diperkenalkan konsep akrual dan kas basis yang digunakan dalam pembuatan jurnal anggaran dan jurnal finansial. Akuntansi pemerinahan berbasis akrual merupakan tindak lanjut dari regulasi PP No. 71 tahun 2010 yang mewajibkan semua institusi sektor publik untuk beralih ke akrual paling lambat tahun 2015. Melalui regulasi tersebut diharapkan dapat meningkatkan akuntabilitas sektor publik. Hal ini sejalan dengan Bisogno \& Cuadrado-ballesteros (2019) yang mendokumentasikan bahwa akuntansi akrual berguna untuk meningkatkan efektivitas pemerintah, yaitu memberikan dampak positif pada layanan yang diberikan kepada warga negara sehingga menjamin keberlanjutan keuangan. Adopsi akuntansi akrual memungkinkan pemerintah menjadi lebih dari akuntabel dimana hal itu dapat mendorong tata kelola untuk mencapai peningkatan dalam kapasitas pemerintah untuk secara efektif merumuskan dan menerapkan kebijakan publik. Salam \& Sutaryo (2019) juga mengungkapkan bahwa penggunaan akuntansi full akrual sesuai dalam menyediakan informasi untuk pengambilan keputusan internal dalam suatu provinsi.

Penggunaan basis akrual pada jurnal finansial dan basis kas pada jurnal anggaran, tentu sedikit berbeda dengan konsep dalam akuntansi komersial yang selama ini dikenal oleh guruguru SMK sehingga pada sesi ini banyak pertanyaan yang dilontarkan oleh peserta. Pada tahap ini peserta menganalisis transaksi contoh kasus yang diberikan untuk memilah transaksi yang masuk jurnal anggaran ataupun jurnal finansial. 

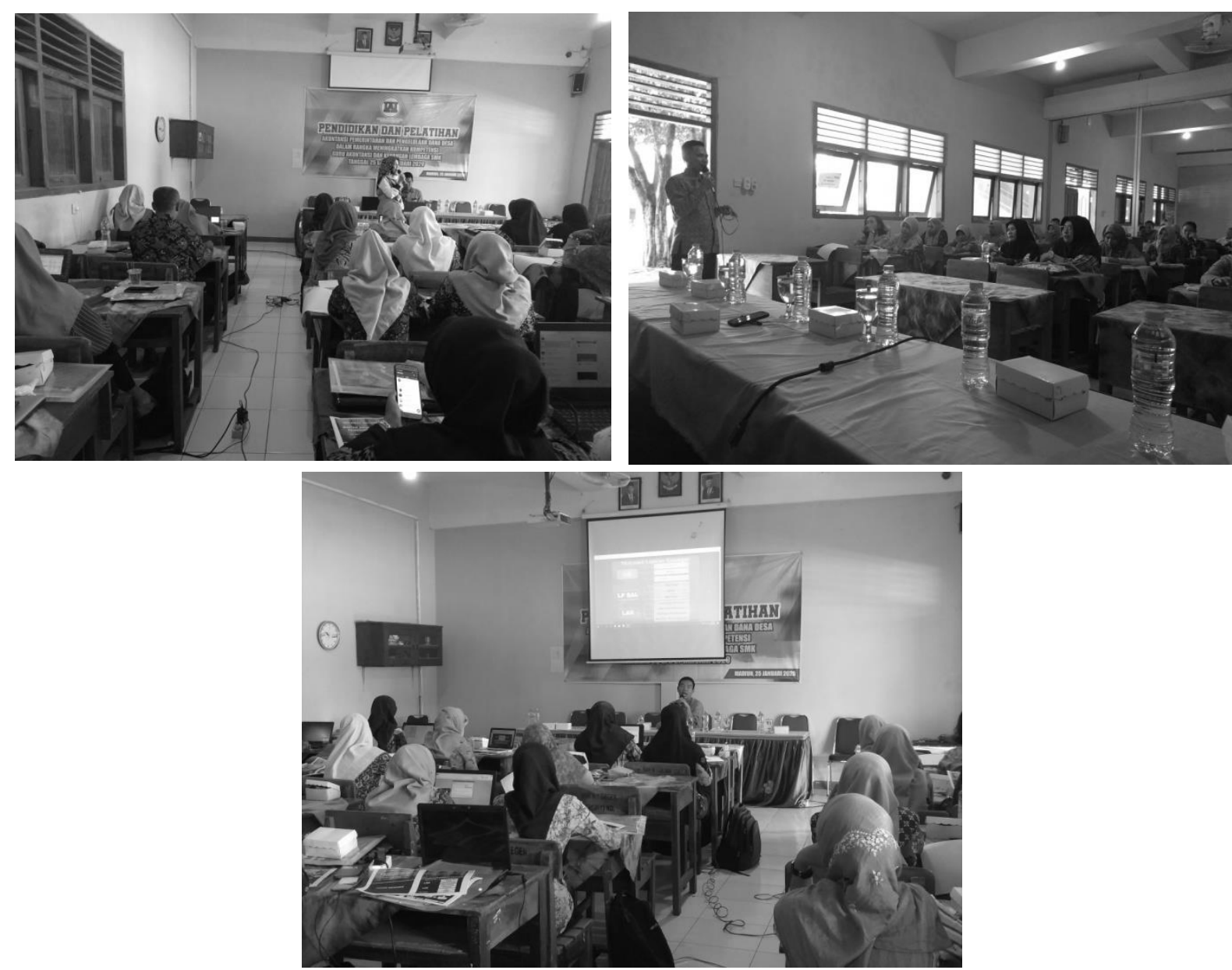

Gambar 2. Pemaparan Materi

Pada pemaparan teori konseptual mengenai akuntansi pemerintahan disampaikan beberapa jenis laporan keuangan dalam struktur akuntansi pemerintahan diantaranya;

1. Laporan Realisasi Anggaran Desa, Laporan Neraca dan Catatan atas Laporan Keuangan Desa disusun oleh jajaran pemerintahan desa.

2. Laporan Realisasi Anggaran, Neraca, Laporan Operasional dan Laporan Perubahan Ekuitas disusun oleh SKPD.

3. Laporan Saldo Anggaran Lebih (SAL) dan Laporan Arus Kas disusun oleh SKPKD.

Pada sesi ini dijelaskan bahwa ketika menyusun laporan pertanggungjawaban anggaran harus paham dimanakah posisinya, tidak boleh melanggar hak dan kewajiban ataupun wewenang pihak lain. Pemateri juga menjelaskan mekanisme UP/ GU/ TU pada akuntansi pemerintahan yang dianalogikan mirip dengan mekanisme kas kecil dalam akuntansi komersial. Pemaparan teori kemudian dilanjutkan dengan mekanisme pelaporan antara SKPD dengan SKPKD yang mirip dengan akuntansi anak dan induk dalam akuntansi komersial tingkat lanjutan (konsolidasi).

Untuk mempermudah pemahaman peserta mengenai mekanisme SKPD dan SKPKD dalam akuntansi pemerintahan, pemateri membuat ilustrasi mengenai akuntansi dalam kehidupan rumah tangga sehari-hari dimana SKPKD merupakan catatan akuntansi bagi orang tua dalam keluarga sedangkan SKPD merupakan catatan akuntansi yang terjadi pada anak. Dimana pada akhir periode semua catatan akuntansi tersebut kemudian dibuat laporan keuangan yang ada akhirnya akan dikonsolidasikan oleh orang tua.

Laporan keuangan konsolidasi dalam instansi pemerintahan mengacu pada regulasi dalam PP 71 tahun 2010 yang sudah menggunakan basis akrual. Hal ini sesuai dengan standar 
akuntansi pemerintahan yang telah mengadopsi International Public Sector Accounting Standards (IPSAS). Beberapa tahun terakhir telah terjadi reformasi akuntansi pemerintahan dari basis kas, basis kas menuju akrual dan perubahan terakhir menjadi basis akrual. Gomes, Busca dan Fernandes (Gomes, Brusca, \& Fernandes, 2019) mendokumentasikan keuntungan dan kerugian negara spanyol dan portulgal dalam mengimplementasikan akuntansi akrual serta peran IPSAS dalam meningkatkan kualitas laporan keuangan. Berdasarkan analisis yang dilakukan ditemukan bahwa perubahan sistem kas basis menjadi akrual dapat meningkatkan kualitas laporan keuangan konsolidasi, namun demikian karena rendahnya pengambilan keputusan yang didasarkan pada laporan keuangan sektor publik menjadikan biaya dan manfaat atas perubahan tersebut tidak sebanding.

Kewajiban untuk menyusun laporan keuangan konsolidasi berbasis akrual di Indonesia sudah dicanangkan sejak tahun 2015. Hal ini dilaksanakan guna meningkatkan kebutuhan transparansi dan akuntabilitas pengelolaan keuangan negara. Sejalan dengan hal itu Arifin (Arifin, 2017) menujukan bahwa peran BPK dan BPKP dalam melakukan pendampingan penyusunan laporan keuangan konsolidasi sudah cukup baik. Hal ini dibuktikan dengan peningkatan jumlah pemda yang memperoleh opini wajar tanpa pengecualian.
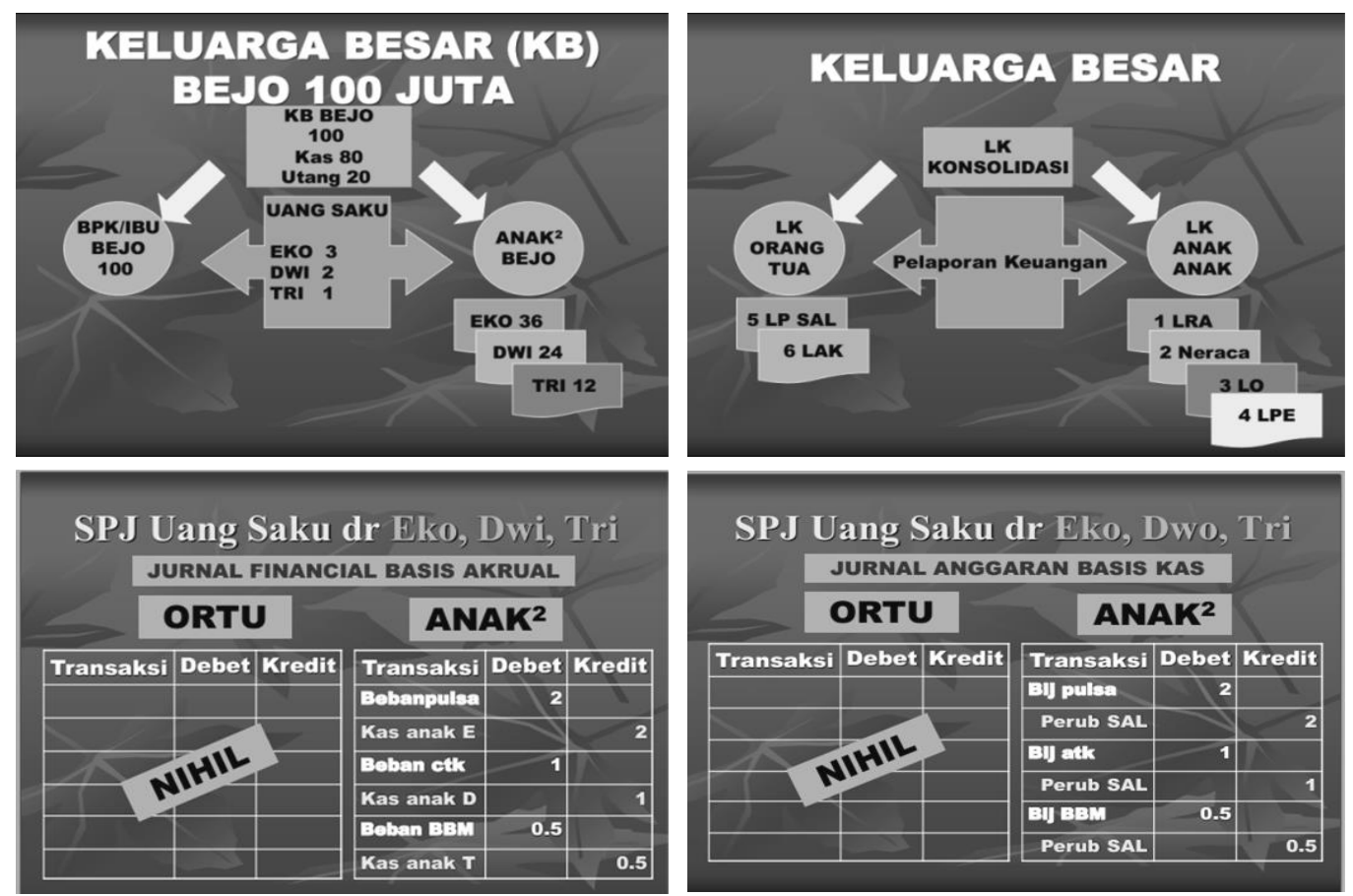

Gambar 3. Simulasi Pencatatan Transaksi Akuntansi Sektor Publik yang Dianalogikan dengan Akuntansi Rumah Tangga

Pada sesi diskusi, beberapa peserta mengungkapkan mengalami kendala karena belum terbiasa dengan nama-nama akun dalam akuntansi pemerintahan yang harus mengikuti Permendagri No. 64 Tahun 2013. Namun demikian secara konseptual, setelah mengikuti pelatihan ini peserta lebih memahami alur dan konsep akuntansi dalam akuntansi pemerintahan. Peserta dapat membedakan mana jurnal yang harus masuk dalam pencatatan SKPD ataupun masuk SKPKD, mana jurnal yang harus masuk dalam laporan realisasi anggaran ataupun laporan operasional berdasarkan kewenangan masing-masing pihak.

Pelatihan hari kedua dilanjutkan pembahasan mengenai mekasime audit atas penggunaan anggaran pada sektor pemerintahan dan simulasi penggunaan aplikasi siskeudes dalam proses penyusunan laporan pertanggungjawaban dana desa. Namun demikian, pembahasan mengenai penggunaan aplikasi siskeudes tidak dapat dibahas secara tuntas karena keterbatasan waktu penyelenggaraan acara pelatihan akuntansi pemerintahan dan pengelolaan 
dana desa. Hal ini terjadi karena fitur siskeudes yang cukup kompleks dan memerlukan informasi yang detail mulai dari perencanaan, penganggaran, penatausahaan dan pembukuan dana desa yang harus selaras dengan RPJM (Rencana Pembangunan Jangka Menengah) Desa.

Pada sesi hari kedua simulasi penggunaan aplikasi siskeudes hanya membahas fitur-fitur aplikasi secara ringkas agar peserta memahami alur penggunaan sistem. Pada sesi ini diberikan penjelasan bahwa menu data entri utama siskeudes meilputi 3 modul yaitu: 1) penganggaran yang merupakan fungsi penyusunan anggaran dengan output utama APBDes, 2) penatausahaan yang merupakan fungsi untuk pelaksanaan APBDes yang telah disusun yang meliputi pengajuan SPP, pencairan dan pertanggungjawaban dengan output buku penatausahaan keuangan desa, 3) pembukuan yang merupakan fungsi penyusunan laporan keuangan pemerintah desa dengan output laporan pelaksanaan anggaran APBDes dan Laporan kekayaan milik desa (Solikhah, Subowo, \& Yulianto, 2018).

Untuk mengoptimalkan penguasaan materi mengenai akuntansi pemerintahan dan pengelolaan dana desa, instrukturikan penugasan mandiri kepada peserta. Dalam hal ini pemateri memberikan buku panduan pengisian data dalam aplikasi siskeudes, untuk menunjang pemahaman peserta dalam melakukan penginputan data dalam aplikasi. Pemateri juga membuka jalur komunikasi untuk pembelajaran secara mandiri ataupun ketika perserta mengalami kendala dalam pemanfaatan aplikasi.

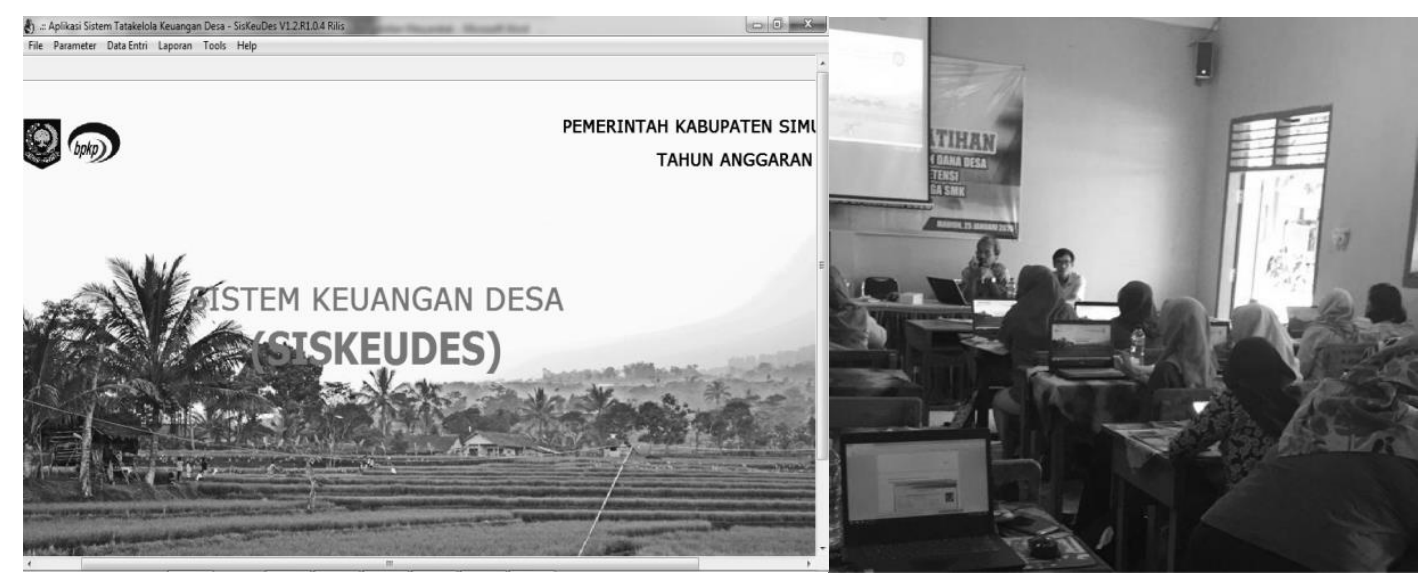

Gambar 4. Simulasi Aplikasi Siskeudes

Secara keseluruhan dapat dikatakan bahwa kegiatan pelatihan akuntansi pemerintahan dan pengelolaan dana desa berjalan lancar dan cukup efektif. Hal ini dibuktikan dengan antusiasme peserta yang mengikuti acara pelatihan dari awal sampai dengan akhir selama 2 hari materi dan pendampingan serta 1 hari penugasan mandiri. Peserta cukup kooperatif dengan datang tepat waktu, mengikuti instruksi yang diberikan oleh pemateri selama kegiatan berlangsung. Berdasarkan wawancara dengan beberapa peserta, mereka mengungkapkan kebermanfaatan program dan meminta pelatihan lanjutan mengenai penggunaan aplikasi siskeudes secara penuh untuk membangun pemahaman secara holistik mengenai pengelolaan dana desa

\section{KESIMPULAN}

Pelatihan akuntansi pemerintahan dan pengelolaan dana desa dapat terlaksana dengan lancar, peserta sangat kooperatif dan kondusif. Hasil dari kegiatan ini peserta telah dapat melakukan analisis transaksi untuk membedakan manakah transaksi yang masuk pada jurnal finansial, dan manakah transaksi yang masuk dalam jurnal anggaran. Peserta juga sudah dapat membedakan ranah dan wewenang dalam proses akuntansi sektor publik, dimana beberapa transaksi tertentu hanya boleh diakui oleh SKPKD dan transaksi lainnya harus masuk dalam SKPD. Pemahaman peserta semakin lengkap dengan materi audit sektor publik yang diberikan. 
Sedangkan pengenalan aplikasi siskeudes hanyalah sebagai komplementer dalam pelatihan ini karena adanya keterbatasan sumber daya dan waktu, yang mungkin akan ditindak lanjuti dengan pelatihan lanjutan di masa yang akan datang.

Kegiatan pelatihan ini sangat terbatas karena hanya dilaksanakan selama 3 hari dengan materi dan praktik yang sangat padat. Kegiatan pelatihan juga kurang optimal karena cukup lama untuk membangun pemahaman konsptual peserta sehingga mengalami kekurangan waktu untuk kegiatan praktik. Untuk itu dalam kegiatan pengabdian selanjutnya diharapkan pemaparan materi secara kospetual dilakukan secara terpisah dengan kegiatan pemanfaatan aplikasi agar dapat berjalan optimal dan kondisi psikologi peserta dalam kondisi optimal, karena pemaparan konsep materi yang cukup panjang akan mengunrangi konsentrasi peserta pada tahap praktik penggunaan aplikasi.

\section{UCAPAN TERIMA KASIH}

Penulis mengucapkan terima kasih kepada beberapa pihak yang telah memberi dukungan finansial terhadap pengabdian ini diantaranya:

1. Rektor Universitas PGRI Madiun

2. Dekan FKIP Universitas PGRI Madiun

3. Ketua Program Studi Pendidikan Akuntansi Universitas PGRI Madiun

4. MGMP Akuntansi dan Keuangan Kabupaten Madiun

5. IAI Komisariat Madiun.

\section{DAFTAR PUSTAKA}

Arifin, M. A. (2017). Standar Akuntansi Pemerintah Dalam Mewujudkan Good Goverment Governance. Jurnal Media Wahana Ekonomika, 13(4), 69-82.

Badan Pusat Statistik. (2015). Persentase Penduduk Usia 10 Tahun Ke atas menurut Pendidikan Tertinggi Yang Ditamatkan, 2012-2013. Kabupaten Madiun. Retrieved from https://madiunkab.bps.go.id/statictable/2015/01/29/82/persentase-penduduk-usia-10tahun-ke-atas-menurut-pendidikan-tertinggi-yang-ditamatkan-2012-2013.html

Bakrun, B. (2019). Perubahan Kurikulum SMK Sebagai Tuntutan. Retrieved March 5, 2020, from https://www.riau.go.id/home/skpd/1970/01/01/2044-perubahan-kurikulum-smksebagai-tuntutan

Bisogno, M., \& Cuadrado-ballesteros, B. (2019). Financial Sustainability of Public Sector Entities. Financial Sustainability of Public Sector Entities, 123-144. https://doi.org/10.1007/978-3030-06037-4

Gomes, P., Brusca, I., \& Fernandes, M. J. (2019). Implementing the International Public Sector Accounting Standards for consolidated financial statements: facilitators, benefits and challenges. Public Money and Management, 39(8), 544-552. https://doi.org/10.1080/09540962.2019.1654318

Hadi, B. (2015). Tantangan Penerapan Kurikulum Akuntansi Pemerintahan untuk SMK Kelompok Keahlian Bisnis dan Manajemen dengan Adanya UU Desa Nomor 6 Tahun 2014. In Seminar Nasional Pendidikan Akuntansi dan Keuangan "Pengembangan Pendidikan Akuntansi dan Keuangan yang Berkelanjutan" (pp. 564-573). Surakarta: UNS. https://doi.org/10.1017/S026502150623028X

Manafe, D. (2019, January 29). Belum Melek Akuntansi, Aparatur Bakal Kesulitan Kelola Dana Desa. Berita Satu. Retrieved from https://www.beritasatu.com/nasional/244773/belummelek-akuntansi-aparatur-bakal-kesulitan-kelola-dana-desa

Salam, A., \& Sutaryo, S. (2019). Kesesuaian Sistem Pelaporan Keuangan Akrual dalam Pengambilan Keputusan Internal di Pemerintah Daerah. Assets: Jurnal Akuntansi Dan Pendidikan, 8(1), 21-34. https://doi.org/10.25273/jap.v8i1.4087

Solikhah, B., Subowo, \& Yulianto, A. (2018). Seminar nasional kolaborasi mewujudkan akuntabilitas pengelolaan dana desa dengan aplikasi SISKEUDES. In SNKPM 1 (2018) 434438 Seminar Nasional Kolaborasi Pengabdian Pada Masyarakat (Vol. 1, pp. 434-438). Semarang. 
Wardi, J., Liviawati, \& Putri, G. E. (2017). IBM UKMK di Bidang Akuntansi dan keuangan Desa di Kecamatan Bunut Kabupaten Pelalawan Provinsi Riau, Indonesia. Dinamisia: Jurnal Pengabdian Kepada Masyarakat, 1(1), 29-34. 